\title{
Occurrence of Macro-algae in the By-catch of Beach Seine Fisheries at Sakumono, Ghana
}

\author{
F. K. E. Nunoo ${ }^{1 *}$ and G. K. Ameka ${ }^{2}$ \\ ${ }^{1}$ Department of Oceanography \& Fisheries, University of Ghana, P. O. Box LG 99, Legon, Ghana; E-mail: \\ fkenunoo@ug.edu.gh \\ ${ }^{2}$ Department of Botany, University of Ghana, P. O. Box LG 55, Legon; E-mail: kgameka@ug.edu.gh \\ *Corresponding author
}

\begin{abstract}
Dense growths of macro-algae contribute to primary productivity in nearshore marine environments and their abundance has been correlated with fish catch. Though the two resources are captured together in beach seine nets, macro-algae are usually regarded as a nuisance by fishermen and discarded (as by-catch). The species composition, abundance and seasonality of macro-algal species in fisheries by-catch of beach seine nets at Sakumono, Ghana were determined between November 1999 and September 2001. Data was analysed using a combination of both univariate and multivariate procedures. The species richness of macro-algae in the catch was high and appeared to vary monthly. Biomass of macro-algae in the catch was found to be low (range 0-6.7\%) and formed only $7.7 \%$ of the by-catch. The significance of macroalgae in by-catch is discussed.
\end{abstract}

\section{Introduction}

The nearshore marine environment, technically, comprises the shoreline, beach, surf zone and nearby offshore areas (Ross, 2000). Its exact expanse is variable depending on the geophysical nature, waves, tides and topography of the area. It serves as a nursery area for fishes and macro-crustaceans (feeding and spawning) and as a shelter from predation (Lasiak, 1981). Macro-algae may occur in rocky areas of nearshore waters and contribute to primary production of such areas. They also provide shelter for juvenile fish as well as protect them from predators (Lenanton, Robertson \& Hausen, 1982; Peters, 1984). Robertson \&Lenanton (1984) have demonstrated a significant correlation between the quantity of macro-algae and the numbers of fish caught in Australian beaches. Fish was two to 10 times more abundant in surf zones with macro-algae.

Marine fisheries in Ghana is dominated by artisanal fishery, which contributes about three-quarters of total marine production (FRUB, 1997). Most artisanal fishermen operate in relatively shallow waters (up to a depth of $30 \mathrm{~m}$ ) on small scale; their operation is labour intensive and they use relatively unsophisticated gear such as beach seines. Beach seining is a popular mode of fishing that is widely practiced on the sandy beaches of Ghana. It contributes a significant $12 \%$ of total artisanal production. There are 790 beach seine units operating from 154 landing beaches along the coast of Ghana (Bannerman, Koranteng \& Yeboah, 2001).

The incidental capture and subsequent discard of non-target species in fisheries catch has attracted worldwide attention in recent years (Saila, 1983; Alverson et al., 1994; Kennelly, 1995; Nunoo, 1998). The non-targeted part of the catch, the by-catch, is defined as "that part of the gross catch which is captured incidentally to the species towards which there is directed effort” (Saila, 1983). The high mortality and destruction of biodiversity from the practice of discarding unwanted species from fisheries catch is likely to adversely affect productivity of the oceans, loss of biodiversity and ecological shifts in species assemblages (Andrew \& Pepperell, 1992; Nunoo \& Evans, 1997; Broadhurst, 2000). Alverson et al. (1994) estimated global discards in commercial fisheries as 27.0 million metric tonnes with a range of 17.9-39.5 million metric tonnes per annum. By-catch formed more than two-thirds of the catch from Ghana's industrial shrimp fisheries (Nunoo, 1998).

Generally, the components of the by-catch vary both temporally and spatially in quality and quantity. Much has been written on by-catch of shrimp trawl fisheries than other fisheries in the world. Components of shrimp fishery by-catch mainly include a variety of fishes, invertebrates, vertebrates such as sea turtles and sea snakes, and litter (Nunoo, 1998). There has been little or no mention of occurrence of macro-algae in by-catch of shrimp fishery. For instance, Nunoo \& Evans (1997) and Nunoo (1998) did not indicate whether or not macro-algae occurred in the catch of offshore industrial shrimp fishery in Ghana. However, Nunoo \& Quayson (2003) recorded the occurrence of dried algae at two sandy beaches in Accra that had ostensibly been left there by wave action and the cleaning of nets of fishers.

In Ghana the marine nearshore area with respect to macro-algae and fish interactions has not been adequately studied. The macro-algae inhabiting the intertidal and subtidal areas have been studied by Lawson and John (1987) and John , Lawson \& Ameka (2003). Other interesting and important aspects of macro-algae and fish interactions are unknown. For instance, the species composition, abundance and seasonality of macro-algal species in fisheries bycatch are unknown. Information on abundance and seasonality, for example, could influence decisions by fishermen with respect to timing of fishing, fishing behaviour and fishing effort (Nash, 1992). The present investigation is the first, to the best of the authors' knowledge, to identify and quantify the algal component of beach seine fisheries catch in the West African sub-region. 


\section{Materials and methods}

Sakumono is a small peri-urban village located along the Accra-Tema highway in Ghana. It is $3 \mathrm{~km}$ west of Tema and about $18 \mathrm{~km}$ east of Accra. The beach occupies an area between two lagoons: Mukwe (near Accra) and Sakumo II (near Tema). Sakumo II lagoon is an internationally and ecologically important Ramsar wetland, noted for its high biodiversity (e.g. migrating shore-birds and waterfowl). The Sakumo II lagoon is opened to the adjacent sea via a culvert. There is daily tidal exchange of waters between the sea and the Sakumo II lagoon. The Sakumono beach is located between $005^{\circ} 57^{\prime} 18^{\prime}$ ' N, $000^{\circ} 58^{\prime} 54^{\prime \prime} \mathrm{E}$ and $005^{\circ} 36^{\prime} 46^{\prime}$ ' N, $000^{\circ} 02^{\prime} 16^{\prime \prime}$ W with maximum water depth ranging between $8.7 \mathrm{~m}$ and $9.7 \mathrm{~m}$ (Fig. 1).

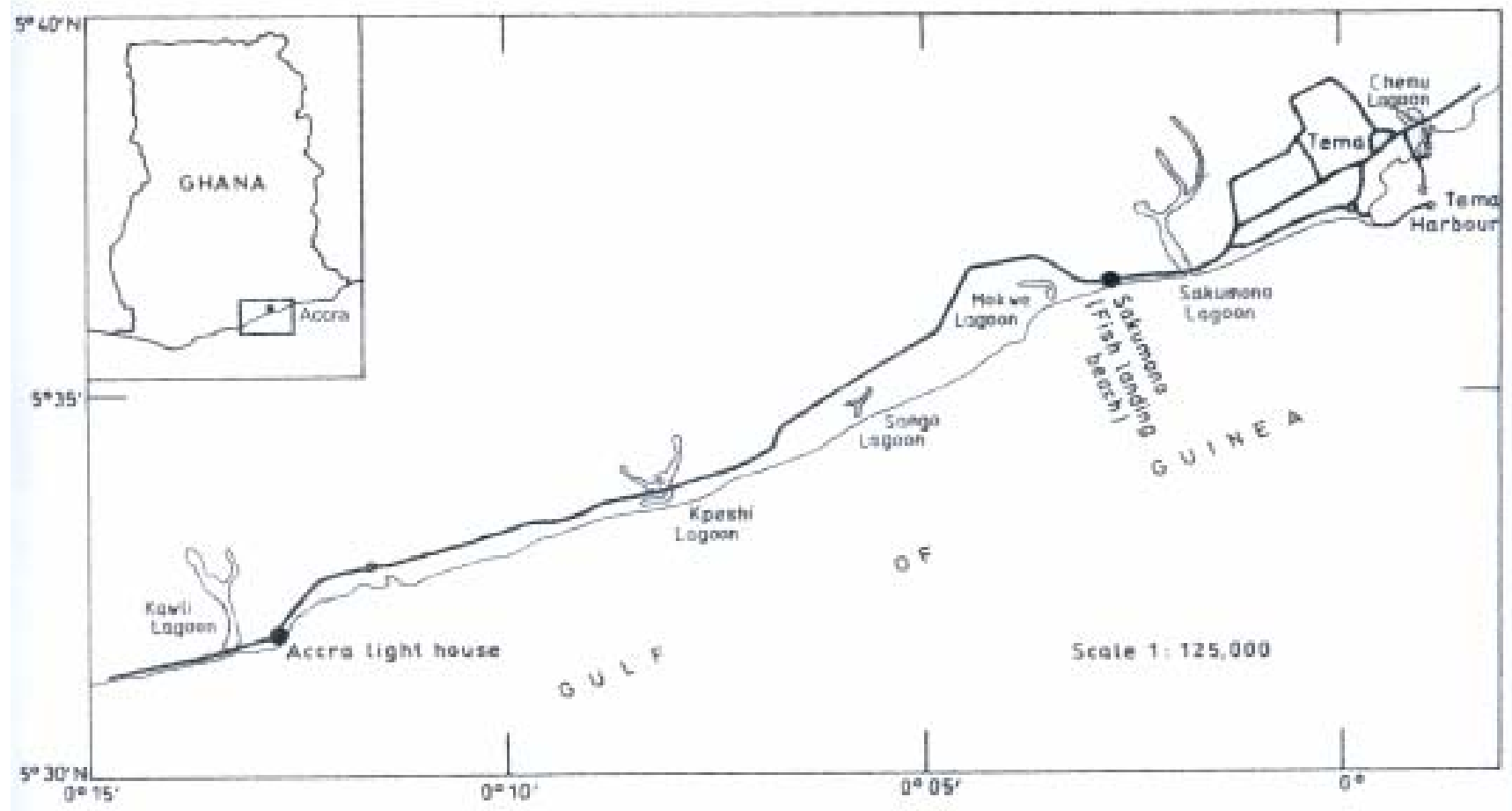

Fig. 1. Map showing the location of Sakumono fish landing beach in Accra, Ghana (after Nunoo, 2003)

Data collection was over a 23-month period from November 1999 to September 2001. The study was entirely fishery-dependent, and because of this there was no sampling in July 2001 when fishermen did not go fishing. Fishing gear and skill of fishers were kept constant as far as possible throughout the study period by sampling from same net and crew. A total of 94 beach seine hauls were sampled during the study period.

When catch was landed, the total biomass in each haul was estimated from the number of full bowls taken (each bowl weighed approximately $5 \mathrm{~kg}$ when full). From each estimated number of bowls from a haul, approximately $10 \%$ of the catch was sampled before normal sorting by fishermen. Each sample from a catch was placed in labelled polyethylene bags and kept in a freezer at a constant temperature of $-40{ }^{\circ} \mathrm{C}$ (within $1 \mathrm{~h}$ of landing). Samples preserved in the freezer were analysed within 7 days. Samples from a given catch were thawed overnight prior to species identification and biomass determination. Macro-algae were taxonomically identified as far as possible using a guide (Lawson \& John, 1987). The biomass of macro-algae in each sample was determined.

The data collected were coded, formatted and analysed using a combination of both univariate and multivariate procedures in the SAS computer software version 8.2 (SAS Institute Inc., 2001). The months of the year were coded starting from January as 1 up to 12 for December. To facilitate a test for seasonality, the months of the year were also coded into four seasons based on wet and dry seasons in Ghana as follows:

Season 1: heavy and wet, months 5-7 (May-July);

Season 2: light and wet, months 8-10 (August-October);

Season 3: light and dry, months 11-1 (November-January);

Season 4: very dry, months 2-4 (February -April). 
Further, all data were first tested to ensure normality and homogeneity of variances. In instances where variances were heterogeneous, $\log _{10}(\mathrm{X}+1)$ transformed data were used. This served to reduce the effect of zeros and large numbers in records.

\section{Results and discussion}

Macro-algae in by-catch of beach seine nets at Sakumono

The catch composition in beach seine nets at Sakumono varied with time but was usually composed of targeted fish (including Sardine, Sardinella maderensis; Barracuda, Sphraena sphyraena; Burito, Brachy-deuterus auritus; West African ilisha, Ilisha africana; Bumper, Chloroscombrus chrysurus; and Cassava croaker, Pseudo-tholithus senegalensis) and crustaceans (including Pink shrimp, Penaeus notialis and Lobster, Panulirus regius) forming 97.5\%. The by-catch included macro-algae, some invertebrates and marine debris (2.5\%). The by-catch, other than algae, in the present investigation is shown in Table 1. Macro-algae formed a mean of $0.75 \%$ (standard error $=0.08$, range $=0-6.65$ ) of monthly catch and $7.69 \%$ of by-catch.

\section{TABLE 1}

\section{Components of by-catch of beach seine nets other than macro-algae}

Faunal by-catch

Thais haemastoma (Phylum Mollusca)

T. nodosa (Phylum Mollusca)

Aurelia auritus (Phylum Cnidaria)

Echinometra lucunter (Phylum Echinodermata)
Marine debris

Pieces of plastics

Pieces of twigs

Pieces of aluminium cans

Pieces of fishing nets

Pieces of Styrofoam

Plastic drinking straws

The macro-algae found in the by-catch are shown in Table 2. Eighteen species in 17 genera were identified. There were seven Chlorophyta, four Phaeophyta and seven Rhodophyta species. The macro-algae are usually attached to rock surfaces in the inter-tidal and sub-tidal areas. Wave action including upwelling and other factors can cause the plants to detach from the substrata and float in the water and become caught in and /or entangled in fishermen's nets.

TABLE 2

Macro-algae in by-catch of beach seine nets at Sakumono

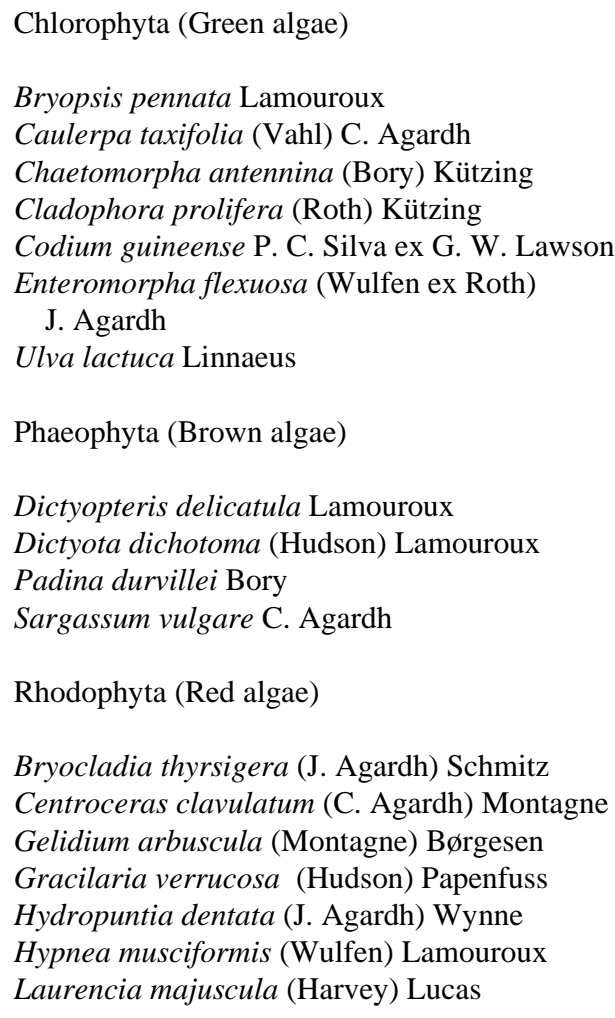


The authors observed that macro-algae got caught in the nets of beach seine fishers resulting in the need to clean nets. The process of cleaning the nets is laborious and time-consuming. During the cleaning process the nets sometimes became damaged and need repair or replacement. Net repair or replacement can represent a huge investment of money and time to the fishermen. It increases expenditure and at the same time reduces income particularly if the net was temporarily out of action and the fishermen could not go to sea. Customers regarded macroalgae as marine debris and hence offered lower prices for fishers' catch that was tainted with macro-algae compared to that of catch without macro-algae. Because of this the fishermen made painstaking efforts to remove the macroalgae before selling their catch.

While macro-algae in by-catch may be undesirable to fishermen the plants might be useful to the student of phycology. Collection of macro-algae for teaching and research in the inter-tidal area is practicable only during low tides at daytime. The variety of algae found in the by-catch indicates that it can be a source of algae for teaching and research at periods when low tide is at night and thus difficult to collect algae during the day. Furthermore, some deep-sea macro-algae (at depths of 10-20 m) might get detached during upwelling and get caught in the fishermen's nets and become part of the by-catch and, thus, become available to the phycologists. Usually deep sea macro-algae are collected by SCUBA divers or collected from the cast-up.

Monthly variation in species composition of macro-algae in by-catch

Table 3 shows the monthly occurrence of macro-algae in by-catch at Sakumono beach. Sargassum vulgare was the most frequently encountered alga. It occurred about $86 \%$ of the time during the sampling period. Nine (Bryocladia, Centroceras, Dictyopteris, Enteromorpha, Hydro-puntia, Hypnea, Padina, Sargassum and Ulva) of the 18 species occurred 50\% or more of the time. Of these, five (Dictyop-teris, Hydropuntia, Hypnea, Sargassum and Ulva) occurred more than $80 \%$ of the time. In recent years, there is an increase in investigating algal products for commercial use. In this respect the species, which occur frequently in the by-catch, could be investigated for use as food supplement (for instance Ulva) and soil additives or amendments (e.g., Hydropuntia and Sargassum by local farmers).

TABLE 3

Monthly occurrence of macro-algae in beach seine nets at Sakumono

('+' indicates presence; '-' indicates absence)

Occurrence of macro-algae

Species

\section{CHLOROPHYTA}

Bryopsis pennata

Caulerpa taxifolia

Chaetomorpha antennina

Cladophora prolifera

Codium guineense

Enteromorpha flexuosa

Ulva lactuca

\section{PHAEOPHYTA}

Dictyopteris delicatula

Dictyota dichotoma

Padina durvillei

Sargassum vulgare
1999

2000

Nov Dec Jan Feb Mar Apr May Jun Jul Aug Sep Oct 
Bryocladia thyrsigera

Centroceras clavalatum

Gelidium arbuscula

Gracilaria verrucosa

Hydropuntia dentata

Hypnea musciformis

Laurencia majuscula
TABLE 3 CONT.

Monthly occurrence of macro-algae in beach seine nets at Sakumono ('+' indicate presence; '-' indicate absence). (Fishing did not occur in July 2001.)

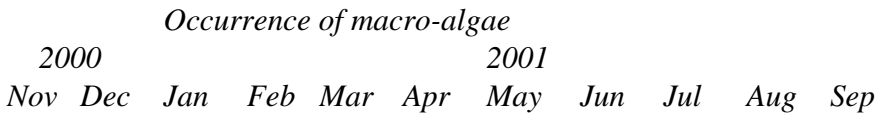

\section{CHLOROPHYTA}

Bryopsis pennata

Caulerpa taxifolia

Chaetomorpha antennina

Cladophora prolifera

Codium guineense

Enteromorpha flexuosa

Ulva lactuca

\section{PHAEOPHYTA}

Dictyopteris delicatula

Dictyota dichotoma

Padina durvillei

Sargassum vulgare

\section{RHODOPHYTA}

Botryocladia thyrsigera

Centroceras clavalatum

Gelidium arbuscula

Gracilaria verrucosa

Hydropuntia dentata

Hypnea musciformis

Laurencia majuscula

Changes in biomass of macro-algae in by-catch

Biomass of macro-algae in the catch per haul was found to be generally low, ranging between 0-6.7\%. Average monthly abun-dance of macro-algae ranged between $0.4-1.72 \%$, and was notably high in the upwelling months of July-September and December-February (Fig. 2). Macro-algal biomass in catch did not vary significantly with season (ANCOVA; $\mathrm{F}=0.87, \mathrm{p}=0.46$ ). The macro-algal biomass formed only $7.7 \%$ of the by-catch. This biomass of macroalgae is generally low compared with that for the targeted fish, which formed $97.5 \%$. Local fishermen have confirmed 
that the weight of the macro-algae in the by-catch is not important to their trade. They maintain, however, that the time spent in sorting and removing algae from both fish and nets is of prime concern to them. Furthermore, according to the fishermen, fish with pieces of algae attached are referred to as 'unclean or tainted fish' and sell at a lower price than fish without attached algae, that is, 'clean fish'. The current investigation, the authors believe, will stimulate research on macro-algae in by-catch in the West African sub-region.

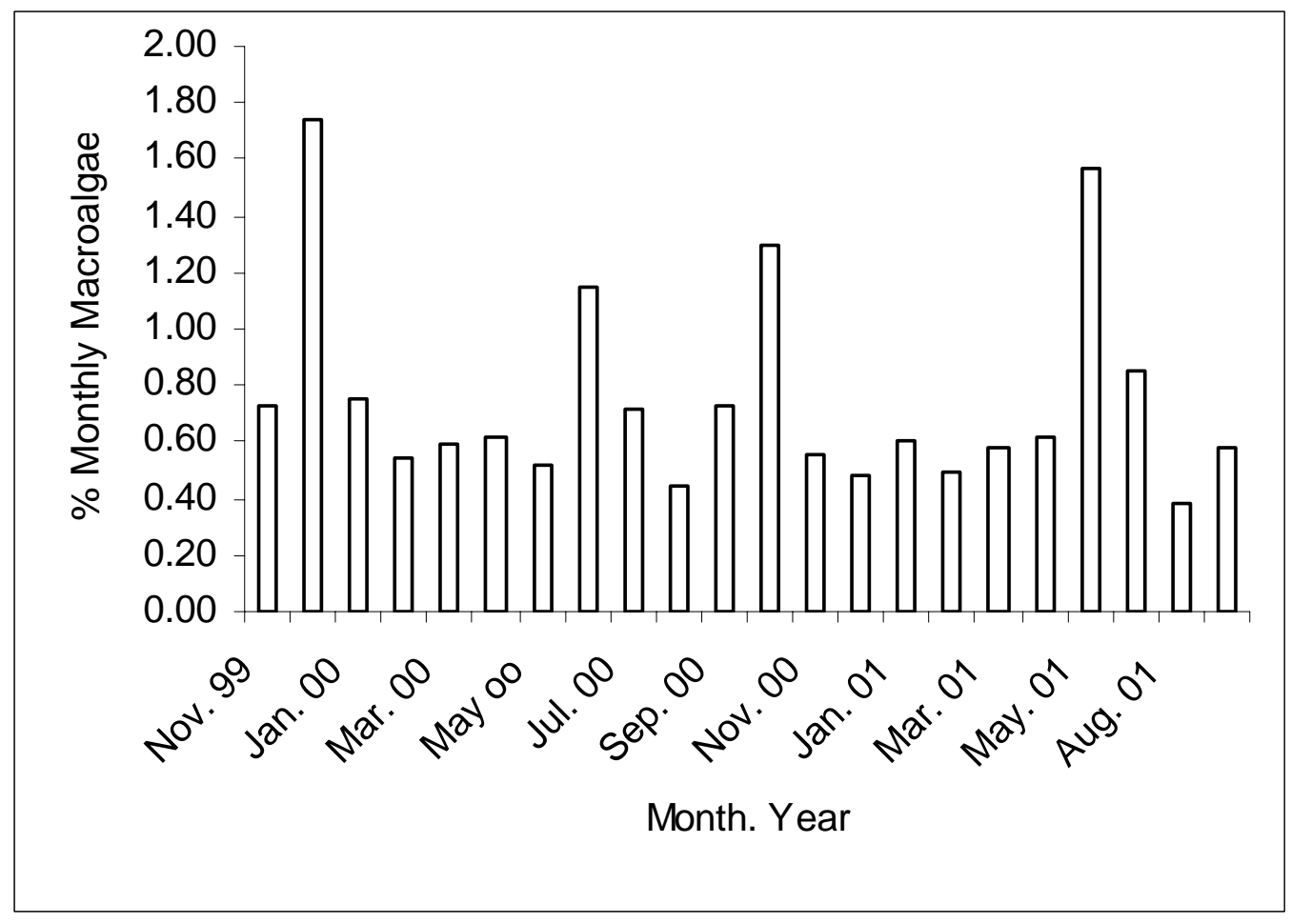

Fig. 2. Average monthly abundance of macroalgae in beach seine nets at Sakumono during November 1999 - October 2001

\section{Acknowledgement}

The authors thank Mr Francis K. Seku of Department of Botany, University of Ghana, Legon, for his help in the laboratory analysis of samples. They are grateful to the IOC of UNESCO which financially supported this study under its TEMA programme.

\section{References}

Alverson D. L., Freeberg M. H., Murawski S. A. and Pope J. G. (1994). A global assessment of fisheries by-catch and discards. FAO Fish. Tech. Pap. 339: 233 pp.

Andrew N. L. and Pepperell J. G. (1992). The by-catch of shrimp trawl fisheries. In Oceanography and Marine Biology: Annual Review (A. D. Ansell, R. N. Gibson and M. Barnes, ed.), 30: 527-565.

Bannerman P. O., Koranteng K. A. and Yeboah C. A. (2001). Report on the canoe frame survey, Ghana. Information Report 31. Tema, Ghana: Marine Fisheries Research Division.

Broadhurst M. K. (2000). Modifica-tions to reduce by-catch in prawn trawls: a review and framework for development. Rev. Fish Biol. Fish. 10: 27-60.

Brown A. C. and McLachlan A. (1990). Ecology of sandy shores. New York: Elsevier. 320 pp.

FRUB (1997). Marine fishing industry of Ghana. Tema, Ghana: Marine Fisheries Research Division.

John D. M., Lawson G. W. and Ameka G. K. (2003). The marine macroalgae of the tropical West Africa subregion. Nova Hedwigia Beih 125. Stuttgart: Gebr. Borntraeger Verlagsbuchhand-lung, Science Publishers.

Kennelly S. J. (1995). The issue of by-catch in Australian demersal trawl fisheries. Rev. Fish Biol. Fish. 5: $213-234$.

Lawson G. W. and John D. M. (1987). The marine algae and coastal environment of tropical West Africa, 2nd edn. Berlin: J. Cramer.

Lasiak T. A. (1981). Nursery grounds of juvenile teleosts: evidence from the surf-zone of King's Beach, Port Elisabeth. S. Afr. J. Sci. 77: 338-390.

Lenanton R. C. J., Robertson A. I. and Hansen J. A. (1982). Nearshore accumulations of detached macrophytes as nursery areas for fish. Mar. Ecol. Prog. Ser. 9: 51-57

Nash A. D. (1992). Impacts of marine debris on subsistence fishermen. An exploratory study. Mar. Pollut. Bull. 24: 150-156. 
Nunoo F. K. E. and Quayson E. (2003). Towards management of litter accumulation -case study of two beaches in Accra, Ghana. J. Ghana Sci. Ass. 5: 145-155.

Nunoo F. K. E. (2003). Biotic, abiotic and anthropogenic controls of nearshore marine fish assemblage caught in beach seines in Sakunono, Ghana, and their management implications. (PhD Dissertation.) University of Ghana, Legon. 155 pp.

Nunoo F. K. E. (1998). By-catch: A problem of the Industrial Shrimp Fishery in Ghana. J. Ghana Sci. Ass. 1: 17-23.

Nunoo F. K. E. and Evans S. M. (1997). The By-catch Problem in the Commercial Shrimp Fishery in Ghana. In The Coastal Zone of West Africa: Problems and Management (S. M. Evans, C. J. Vanderpuye and A. K. Armah, ed.) Proceedings of the 1st International Seminar on Coastal Zone Management in West Africa, Accra, 25-29th March, 1996. UK: Penshaw Press.

Peters D. J. (1984). Seasonality, residency and spatial distribution of juvenile surf zone fishes of the Florida east coast. (MSc Thesis.) Florida Institute of Technology.

Robertson A. I. and Lenanton R. C. J. (1984). Fish community structure and food chain dynamics in the surf-zone of sandy beaches: the role of detached macrophyte detritus. J. Exp. Mar. Biol. Ecol. 84: 265-283.

Ross D. A. (2000). The fisherman's ocean. USA: Stackpole Books. 299 pp.

Ryther J. H. (1969). Photosynthesis and fish production in the sea. Science 166: 72-76.

Saila S. B. (1983). Importance and assessment of discards in commercial fisheries. FAO Fishery Circular, 765: 62 pp.

SAS Institute Inc. (2001). SAS release 8.2 computer software. Cary, NC, USA. 